\title{
Effect Nigella sativa extract for balancing immune response in pristane induced lupus mice model
}

\author{
Theofilus Guritno $^{1}$ (D), Wisnu Barlianto $2^{*}$ (D), Desy Wulandari² (D), Winna Adelia Amru³ \\ ${ }^{1}$ Faculty of Medicine, Universitas Brawijaya, Malang, Indonesia. \\ ${ }^{2}$ Department of Pediatric Allergy Immunology, Saiful Anwar Hospital, Faculty of Medicine, Universitas Brawijaya, Malang, Indonesia. \\ ${ }^{3}$ Faculty of Medicine, Universitas Brawijaya, Malang, Indonesia.
}

\begin{tabular}{l}
\hline ARTICLE INFO \\
\hline Received on: $24 / 02 / 2021$ \\
Accepted on: $25 / 04 / 2021$ \\
Available online: $05 / 07 / 2021$
\end{tabular}

\section{Key words:}

Nigella sativa, SLE, anti-

dsDNA, Treg.

\begin{abstract}
Systemic lupus erythematosus (SLE) is a chronic autoimmune disease with wide manifestations that require long-term treatment. Current treatment has not shown a satisfying result and still yields some side effects. Nigella sativa (NS) has anti-inflammatory and immunomodulatory effects and thus has the potential to improve SLE symptoms. This study aims to understand the NS effect on the level of anti-dsDNA and Treg percentage in pristane-induced lupus (PIL) mice. Anti-dsDNA has an important role in diagnosing and prognosing SLE with high specificity. Treg has been known to be disturbed in SLE. This is a true experimental, randomized posttest only controlled group design with 25 female Bagg and Albino/c mice as the subject, divided into five groups: negative control/K(-)/healthy mice, positive control $/ \mathrm{K}(+) / \mathrm{PIL}$ mice, and three treatment groups (three different doses of NS, 1.2, 2.4, and $4.8 \mathrm{~g} / \mathrm{kgBW} /$ day). AntidsDNA analysis was conducted using enzyme-linked immunosorbent assay and Treg using flow cytometry. Treatment group $4.8 \mathrm{~g} / \mathrm{kgBW} /$ day has significantly lower anti-dsDNA and significantly higher Treg than $\mathrm{K}(+)(p<0.01)$. Linear regression test showed that escalation of NS dose is correlated with the decrease of anti-dsDNA and increase of Treg in PIL mice. Thus, NS has the potential to repair the immune function in SLE.
\end{abstract}

\section{INTRODUCTION}

Systemic lupus erythematosus (SLE) is a chronic debilitating autoimmune disease that affects various organ systems simultaneously or sequentially and undergoes flare-up and remission stage (Jaryal and Vikrant, 2017). SLE requires a long-time treatment. The complexity and the long-term requirement of SLE therapy can burden patients psychologically, which slow down the treatment and leads to mistreatment (Rubinstein et al., 2018). Twothirds of SLE patients experience lupus nephritis that contributes to the main cause of patients mortality (Jaryal and Vikrant, 2017). SLE is a common autoimmune disease that presents various clinical manifestations, thus called "The Disease of A Thousand Faces" (Pan et al., 2020). The high number of these diseases is shown in the

\footnotetext{
*Corresponding Author

Wisnu Barlianto, Department of Pediatric Allergy Immunology, Saiful Anwar Hospital, Faculty of Medicine, Universitas Brawijaya, Malang, Indonesia.E-mail:wisnu_barlian@ub.ac.id
}

epidemiological data in The USA, where the SLE patient number was 1.5 million (Benaroya Research Institute, 2019). Nine out of 10 patients diagnosed with lupus are women, thus biologic sex is important in disease development (Cunningham et al., 2016). It was estimated that there was a role of estrogen in the high incidence of SLE in women, based on the theory that the immune cells have an estrogen receptor (Maidhof and Hilas, 2012).

The latest journal mentioned that the SLE cannot be cured because the present treatment is still only targeting symptomatic relief. It is due to the etiology of this disease which is still hard to be discovered; thus, the specific therapy is also still hard to be determined (Atik et al., 2020). The three major common etiologies of SLE are genetic, hormonal, and environmental factors (Finzel et al., 2018). Physiologically, the cell will undergo apoptosis and then immediately be phagocytized due to the cell surface alteration caused by the apoptosis process (Miles et al., 2012). Meanwhile, in SLE, there is a clearance defect of the apoptotic cells; thus, the phagocytosis does not happen immediately.

SLE is an autoimmune disease marked by the production of various antibodies toward self-nucleus, antinuclear antibodies 
(ANAs), which includes anti-dsDNA that acts as a diagnosis and prognosis of SLE. ANA and anti-dsDNA have high sensitivity and specificity in patients with SLE (Wichainun et al., 2013). AntidsDNA level has been recognized as the classification criteria for SLE by the American College of Rheumatology (ACR) and Systemic Lupus International Collaborating Clinics (SLICC) (Rekvig, 2015). Therefore, the first variable determined in this research was anti-dsDNA.

Cells that undergo secondary necrosis can trigger the release of danger-associated molecular patterns that stimulates inflammatory cytokine response and contributes to the autoimmunity process (Mahajan et al., 2016). Thus, inflammation has become one important target in many studies because inflammation is triggered by autoimmune itself. Moreover, Treg regulation also becomes a relatable research to an immunomodulatory function. Earlier studies stated that Treg dysfunction underlies autoimmunity (Tahernia et al., 2017). Treg cells hold an important role in maintaining peripheral tolerance and prevent autoimmune diseases (Barlianto et al., 2018).

Heretofore, the treatments are given to the SLE patients such as corticosteroid and immunosuppressant that only treat symptomatically but do not decrease SLE progressivity (Hersh et al., 2009). Treatment of SLE patients is a long-term medication and the drug side effect needs to be considered. One of the complications caused by the drug side effect is lupus nephritis (Fanouriakis et al., 2019). From the latest update, there is an emerging interest in studying herbal benefits for SLE. Some studies discovered that some herbal medicine has an anti-inflammatory effect, while some other herbals have the potential to be an immunomodulator. In this research, we would like to apply a new attempt in searching for SLE solutions, by using a herbal that has both anti-inflammatory and immunomodulatory effect, which is Nigella sativa (NS) (Manan and Hussain, 2016). This herbal plant from the Ranunculaceae family is often used as a traditional medicine in the middle east, India, and another Asian region (Botnick et al., 2012). Since Hippocrates and Galen era, this herbal plant has been a medicine for various diseases and symptoms such as bacterial and parasite infection, headache, toothache, and lepra (Botnick et al., 2012). Some of the active compounds in NS are thymoquinone (30\%$48 \%)$, dithymoquinone, and p-cymene $(7 \%-15 \%)$. Thymoquinone is one of the bioactive metabolites in NS that has been known to have an anti-inflammatory and immunomodulatory effect (Ahmad et al., 2013). Both effects have also been proven in the earlier study by Barlianto et al. (2018) that NS can improve the clinical outcome in asthma patients by increasing Treg function There have been many studies that supported that NS was useful for various diseases, yet there have not been many studies about NS on SLE; thus, there is still a big opportunity for researchers to explore more about this. In this research, we aim to understand the effect of NS extract in the lupus mice model by analyzing its effect on the antidsDNA level and Treg cell percentage in pristane-induced lupus (PIL) mice model.

\section{MATERIALS AND METHODS}

\section{Preparation of experimental animals}

Twenty-five female Bagg and Albino (BALB)/c mice (6-8 weeks) were adapted in the Animal House, Faculty of
Medicine, Universitas Brawijaya. The water and food were given ad libitum. The wood husks were replaced every 3 days. The study protocol was approved by the Ethical Committee for Animal Experimentation in the Faculty of Medicine, Universitas Brawijaya (325/EC/KEPK-S1-PD/11/2019).

\section{Induction of lupus}

A total of $20 \mathrm{BALB} / \mathrm{c}$ mice were injected with pristane (Sigma-Aldrich, Saint Louis, MO) intraperitoneally at a dose of $0.5 \mathrm{ml}$ (concentration of $782 \mu \mathrm{g} / \mathrm{ml}$ ). Sixteen weeks after injection, clinical manifestations of lupus were observed in the mice. The treatment was given after clinical findings of lupus.

\section{Extraction of NS}

The seeds of NS were mashed and then extracted with ethanol solvent using the soxhletation method. The resulting mixture was vortexed for 1 minute and sonified for 20 minutes. After that, it was incubated with ethanol solution for 24 hours in a constant Rotamix and Soxhlet machine, then revortexed for 1 minute, and centrifuged for 25 minutes at 1,400 rpm.

\section{Measurement of anti-dsDNA antibody levels using ELISA}

Serum anti-dsDNA antibody levels were detected by mouse anti-dsDNA IgG enzyme-linked immunosorbent assay (ELISA) kit (MyBiosource) following the manufacturer's protocol. The primary antibody was diluted using Phosphate Buffer Saline (PBS) (1:500). After incubated for 1 hour, it was washed using Phosphate Buffer Saline Tween (PBS-T) 0.2\%. Streptavidinhorseradish peroxidase $(1: 1,000)$ was added and incubated for 1 hour. Substrate sureblue TBM was added and incubated for 30 minutes. Without removing the sureblue TBM, the reaction was stopped with $\mathrm{HCl} 1 \mathrm{~N}$ that incubated for 15 minutes. The results were read using ELISA reader $(\lambda=450 \mathrm{~nm})$.

\section{Treg cell percentage measurement using flow cytometry}

The isolation of lymphocyte cells from spleen was carried out by grinding them in PBS. Then, the sample was transferred into a $15 \mathrm{ml}$ propylene tube and PBS was added. Samples were centrifuged for 5 minutes at a speed of 2,500 rpm and temperature of $10^{\circ} \mathrm{C}$ using a Refrigerated Centrifuge (Hermle Z326K). After that, the pellet was stained with fluorescein isothiocyanate AntiMouse Antibody (Biolegend) for 20 minutes. After surface staining, the cells were stained with PE Anti-Mouse CD4 + CD25 + FoxP3 + IL10 (Biolegend) Antibody for Treg cells and incubated for 30 minutes. The stained cells were transferred to the cuvette for flow cytometry analysis using a BD FACS Calibur Flow Cytometer.

\section{Statistical analysis}

A one-way analysis of variance (ANOVA) was used to analyze all the data. Statistical analysis was done using Statistical Product and Service Solution software version 25.

\section{RESULTS AND DISCUSSION}

\section{Clinical manifestations of PIL mice}

We first analyzed SLE clinical symptoms that appeared 16 weeks after the mice were induced by pristane. Some of the clinical manifestations of SLE in PIL mice in this study were shown 
Table 1. Characteristics of PIL mice on 20th weeks.

\begin{tabular}{|c|c|c|c|c|c|}
\hline \multirow{2}{*}{ Groups } & \multirow{2}{*}{$\begin{array}{c}\text { Negative } \\
\text { control }\end{array}$} & \multirow{2}{*}{$\begin{array}{l}\text { Positive } \\
\text { control }\end{array}$} & \multicolumn{3}{|c|}{ N. sativa } \\
\hline & & & Dose 1.2 & Dose 2.4 & Dose 4.8 \\
\hline Number of mice with alopecia + & 0 & 5 & 5 & 4 & 4 \\
\hline Number of mice with arthritis + & 0 & 5 & 3 & 3 & 3 \\
\hline Mean of body weight & 34.36 & 24.50 & 30.59 & 30.92 & 33.23 \\
\hline
\end{tabular}
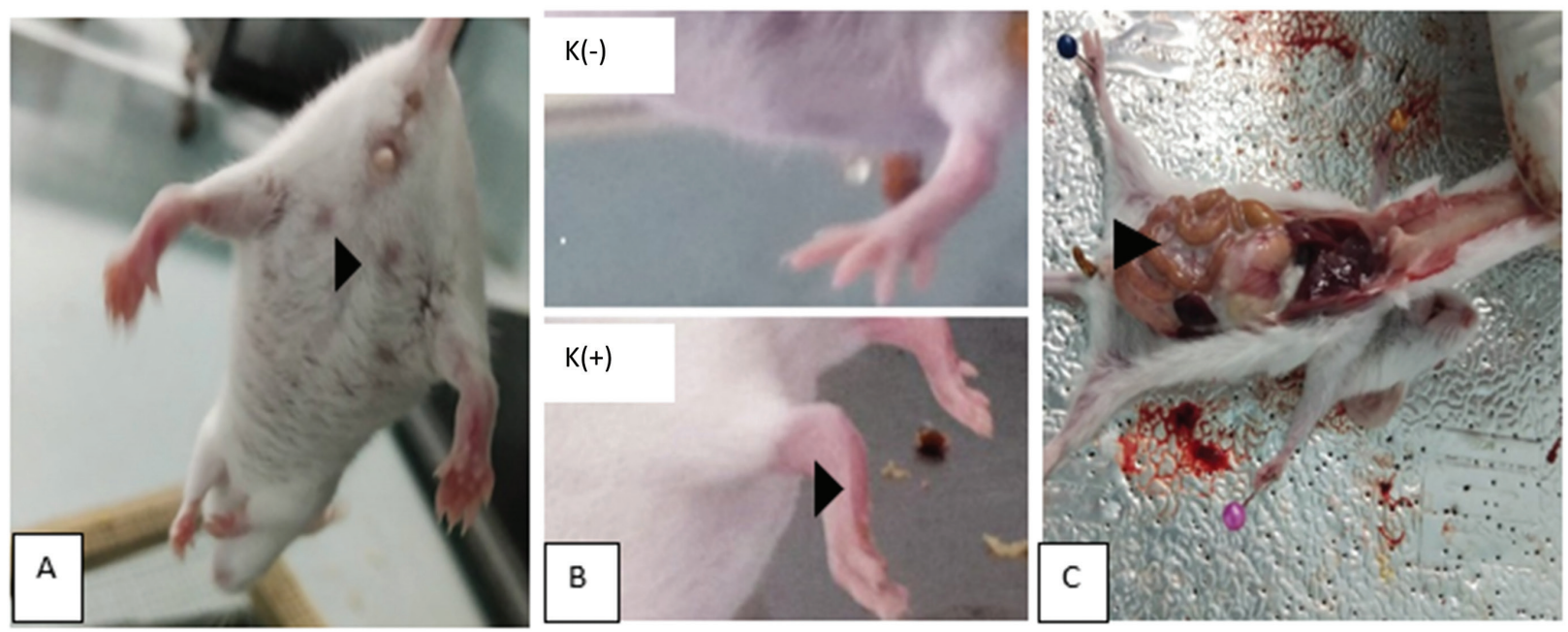

Figure 1. Clinical manifestation of PIL mice after being injected with single-dose pristane intraperitoneally. (A) Alopecia (Black arrow), (B) arthritis in $\mathrm{K}(+)$ when compared with $\mathrm{K}(-)$ (black arrow), and (c) ascites (black arrow).

in Table 1 and Figure 1. According to the latest lupus diagnostic criteria, SLICC, and ACR, PIL mice showed manifestations such as alopecia, arthritis, and the formation of anti-dsDNA (Petri et al., 2012). In this research, ascites was found a lot in the positive control group. There are two mechanisms that are expected to cause ascites in lupus: first, self-reactive B lymphocyte produces an antibody that bound to the circulated antigen, forming an immune complex deposited on the peritoneum thus causing local inflammation; second, vasculitis occurs in the blood vessels of the peritoneal or serous membrane of the abdominal organ, thus producing exudate (Petri et al., 2012).

\section{Serological manifestation of BALB/c PIL mice}

Autoantibody and the immune complex are contributing to the tissue damage in SLE. There are many autoantibodies in SLE, but anti-dsDNA is used for diagnosing and monitoring the development of SLE disease. The mean of the results of antidsDNA levels between PIL mice and normal mice is shown in Table 2. The increase of anti-dsDNA level in serum can cause a relapse in SLE disease activity (Infantino et al., 2018). NS therapy was done for 1 month. Previously, a study by Balaha et al. (2012) has done a NS therapy orally for 1 month in bronchial asthma model BALB/c mice and shows a significant decrease of airway hyperresponsiveness and a balance Th1 and Th2 that contributes to the pathogenesis of SLE.

\section{The effect of NS on the level of anti-dsDNA in PIL mice}

The increase of anti-dsDNA levels in SLE is caused by the function of Th2 cells that increased more than normal, leading
Table 2. Mean of anti-dsDNA level between PIL mice and normal mice.

\begin{tabular}{ccc}
\hline Groups & Anti-dsDNA level $(\mathbf{n g} / \mathbf{m l})$ & $\boldsymbol{p}$-value \\
\hline PIL mice $(n=5)$ & $55.97 \pm 0.37$ & 0.009 \\
Normal mice $(n=5)$ & $43.33 \pm 2.10$ & \\
\hline
\end{tabular}

to the overreactivity of B cell, thus producing autoantibody and causing tissue damage (Atik et al., 2020). In this study, the antidsDNA levels in PIL mice have been proven to increase due to pristane injection. This corresponds to a study by Albaar et al. (2019) that found an increase in anti-dsDNA on the twelfth week after pristane injection.

Thymoquinone in NS can decrease the production of reactive oxygen species which is one of the main factors in SLE pathogenesis (Huang and Pearl, 2018). In the autoimmune disease, NS has been tested in the sclerotic multiple diseases using an Experimental Autoimmune Encephalomyelitis (EAE) mice model and shows a suppression in the inflammation that happens in EAE mice. NS also has increased the remyelination in cerebellum and decreased the expression of Transforming Growth Factor $\beta 1$ (Noor et al., 2015). The immunomodulation effect of NS dose $4.8 \mathrm{~g} / \mathrm{kgBW} /$ day, given as long as 9 weeks, can increase the total number of Tregs significantly in asthmatic mice model (Barlianto et al., 2012).

Anti-dsDNA level was measured by ELISA based on an intracardiac blood sample. The result calculation of anti-dsDNA levels between five groups is shown in Figure 2 and Table 3. The treatment group dose of 1.2 and $2.4 \mathrm{~g} / \mathrm{kgBW} /$ day is not significantly different from the positive control, which is probably 


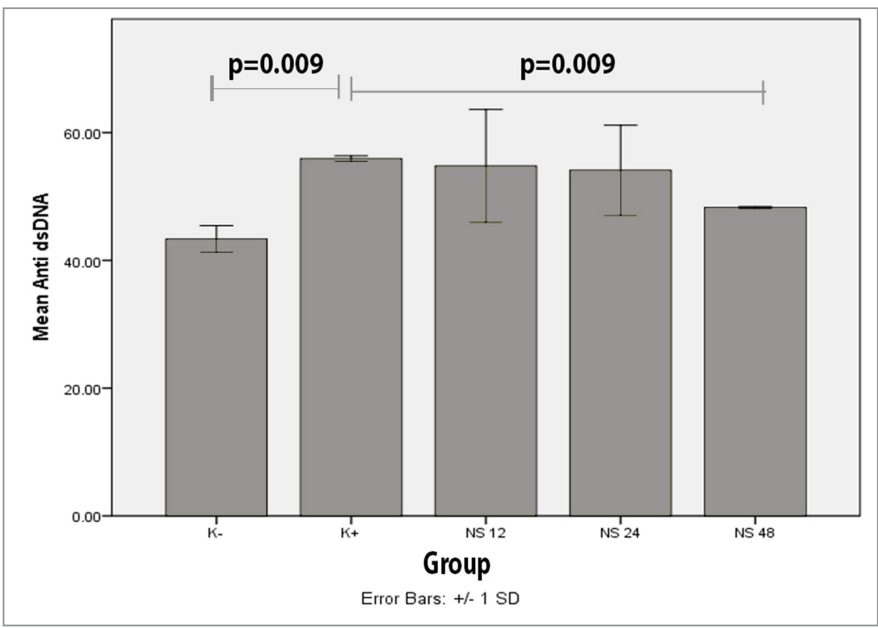

Figure 2. Diagram of anti-dsDNA level ( $\mathrm{ng} / \mathrm{ml})$ mean between groups.

Table 3. Anti-dsDNA level (ng/ml) mean between groups.

\begin{tabular}{cc}
\hline Groups & Mean \\
\hline Negative control K(-) & $43.33 \pm 2.10$ \\
Positive control K(+) & $55.97 \pm 0.37$ \\
NS $1.2 \mathrm{~g} / \mathrm{kgBW} /$ day & $55.90 \pm 6.30$ \\
NS $2.4 \mathrm{~g} / \mathrm{kgBW} /$ day & $54.10 \pm 7.06$ \\
$\mathrm{NS} 4.8 \mathrm{~g} / \mathrm{kgBW} /$ day & $48.25 \pm 0.14$ \\
\hline
\end{tabular}

Table 4. Mann-Whitney significance value between negative control group with positive control groups.

\begin{tabular}{ccc}
\hline Group 1 & Group 2 & $\boldsymbol{p}$-values \\
\hline $\mathrm{K}^{-}$ & $\mathrm{K}+$ & 0.009 \\
& NS 1.2 & 0.009 \\
& NS 2.4 & 0.016 \\
& NS 4.8 & 0.009 \\
K+ & NS 1.2 & 0.917 \\
& NS 2.4 & 0.917 \\
& NS 4.8 & 0.009 \\
NS 1.2 & NS 2.4 & 0.754 \\
& NS 4.8 & 0.076 \\
NS 2.4 & NS 4.8 & 0.117 \\
\hline
\end{tabular}

because these two doses have not reached the therapeutic window of NS for SLE, while dose $4.8 \mathrm{~g} / \mathrm{kgBW} /$ day has been proven to be effective in the previous study using asthmatic mice model (Barlianto et al., 2012).

Based on the Kruskal-Wallis test, a significance value of $p<0.05$ was obtained, which means that there is a statistically significant difference between two or more groups. After that, it was followed by the Mann-Whitney test to determine the comparison of the mean levels of anti-dsDNA. From MannWhitney test, the mean of the negative control group compared to the positive control had a significant difference of $p=0.009$ (Table 4).

From the results of the linear regression test (Fig. 3), it was found that the anti-dsDNA levels tend to decrease with the

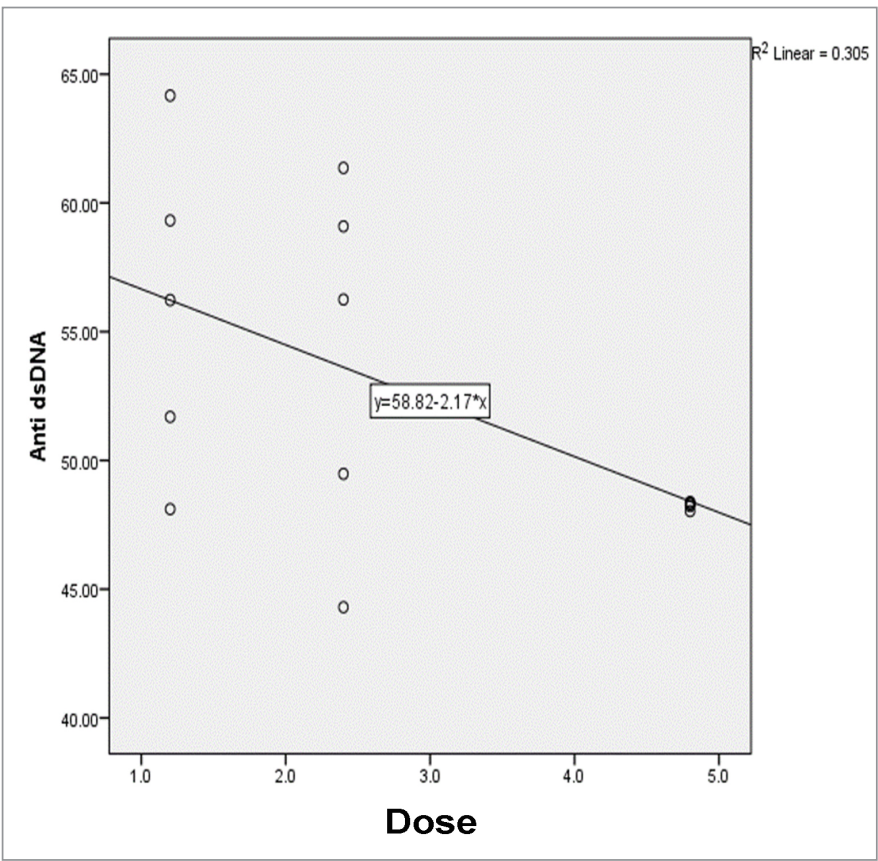

Figure 3. Graph of simple linear regression equation between $N$. sativa dose and anti-dsDNA level in treatment groups.

increasing of NS extract dose. This result corresponds to the other studies about the effect of NS to autoimmune disease-specific autoantibodies, such as the study of Hashimoto thyroiditis where NS can decrease the vascular endothelial growth factor (VEGF) serum level, the autoantibody that is involved in Hashimoto thyroiditis, after 8 months of therapy (Farhangi et al., 2016). Another study shows that NS can improve the clinical symptoms and glucose level and decrease the islet cell autoantibody serum level in a mice model of type 1 diabetes (Hmza et al., 2013).

There are several mechanisms that support the potential of NS in decreasing anti-dsDNA levels. The first mechanism: NS can repair the balance of Th1 and Th2 cells (Balaha et al., 2012). In SLE, this balance is damaged. Most references stated that in SLE cause a decrease in Th1 function and increase in Th2 function that causes excessive B cell activation, increasing autoantibody production including anti-dsDNA. A few references stated that Th1 is more dominant in SLE, especially in the case of lupus nephritis (Pan et al., 2020). Improvement of Th1 and Th2 balance can reduce the hyperreactivity of immune cells and decrease the anti-dsDNA level in the circulation.

The second mechanism: it has been proven that NS extract can increase the number of Treg cells and decrease the number of Th17 cells (Barlianto et al., 2018). Th17 is a subtype of T CD4+ cell that can produce some inflammatory cytokine including IL-17. IL-17 is the main cytokine that supports Th17 role in the pathogenesis of SLE. It has been proven that IL-17 increases in lupus nephritis patients. Treg is able to modulate the function of effector $\mathrm{T}$ cell, maintaining immune homeostasis and preventing autoimmunity. Treg cell is found to decrease in SLE patient. In a normal condition, Th17 and Treg are in the state of dynamic equilibrium condition. This equilibrium state does not occur in SLE (Pan et al., 2020). Thus, the ability of NS in increasing Treg and decreasing Th17 can return to the equilibrium state. 
The difference of anti-dsDNA level dose of 1.2 and 2.4 $\mathrm{g} / \mathrm{kgBW} /$ day is not significant compared to the positive control. Beside the dose factor that has not reached the therapeutic dose, this can also be the influence by stress factor. Studies have shown that therapy toward mice using the orogastric lavage method can induce significant stress characterized by the increase of blood pressure, heartbeat, and plasma cortisone level (Walker et al., 2012). There are many studies in human and animal that shows the influence of various stressor toward immune function. Stress can induce inflammation, characterized by the presence of cytokine and acute phase reactant cytokine that is related to some metabolic disease, including IL-6 and the effects that it generates (Stojanovich, 2010).

Stress can interfere in the balance of Th1 and Th2, those involved in the pathogenesis of many diseases including autoimmune. A study using BALB/c mice given a stressor shows the decrease of $\mathrm{T}$ cell proliferation and the increase of $\mathrm{B}$ cell proliferation (Palumbo et al., 2010). In dose $4.8 \mathrm{~g} / \mathrm{kgBW} / \mathrm{day}$, the therapeutic effect is more capable of complementing the stress effect caused by routine care and treatment in mice; thus, the anti-dsDNA result that was obtained can be significantly lower compared to the positive control group. However, the mean of anti-dsDNA level of all the treatment groups is still lower than the positive control. Thus, it can be concluded that NS has the potential to lower the anti-dsDNA in SLE.

\section{The effect of NS on the number of Treg cells in PIL mice}

The percentage of $\mathrm{T}$ regulator (Treg) was measured by flow cytometry from the mice spleen. The markers used to measure the percentage of cell counts were $\mathrm{CD} 4^{+} \mathrm{CD} 25^{+} \mathrm{Foxp} 3^{+} \mathrm{IL} 10^{+}$. The results of flow cytometry on Foxp $3^{+}$IL $10^{+}$marker from each group are shown in Figure 4. Based on the one-way ANOVA test, a significance value of $p<0.05$ was obtained, which means that there was a statistically significant difference between two or more groups. After the one-way ANOVA test, it was followed by the post hoc Tukey test to determine the comparison of the Treg percentage mean between groups. The results of the post hoc Tukey test are shown in Table 5. From the linear regression test (Fig. 5), it was found that the correlation/relationship $(R)$ was 0.930 , and the determination coefficient ( $R$ Square) was 0.865 , which means that the effect of NS dose on the Treg percentage was $86 \%$ ( $p=0.000)$. From the results of the linear regression test, it was found that the Treg percentage tends to increase with the increase of NS extract dose.

The pathogenesis of SLE is caused by the loss of tolerance of B cells and T cells. In the mid-19th century, B-cell autoreactivity was first discovered as a major component of SLE. However, in subsequent studies, it was also found that $\mathrm{T}$ cells play a role in the pathogenesis of SLE, especially related to the mechanism of systemic inflammation (Rottman and Willis, 2010). That mechanism is also used as the basic principle of pristane injected intraperitoneally as an inducing agent for lupus mice model, which is able to induce the formation of autoreactive B cells and $\mathrm{T}$ cells and reduce the number and activation of regulatory $\mathrm{T}$ cells (de Zubiria Salgado and Herrera-Diaz, 2012).

It was explained that the tolerance failure of $\mathrm{B}$ and $\mathrm{T}$ cells was caused by a decrease in the number and function of Treg cells (Pan et al., 2020). In addition, newly diagnosed SLE patients

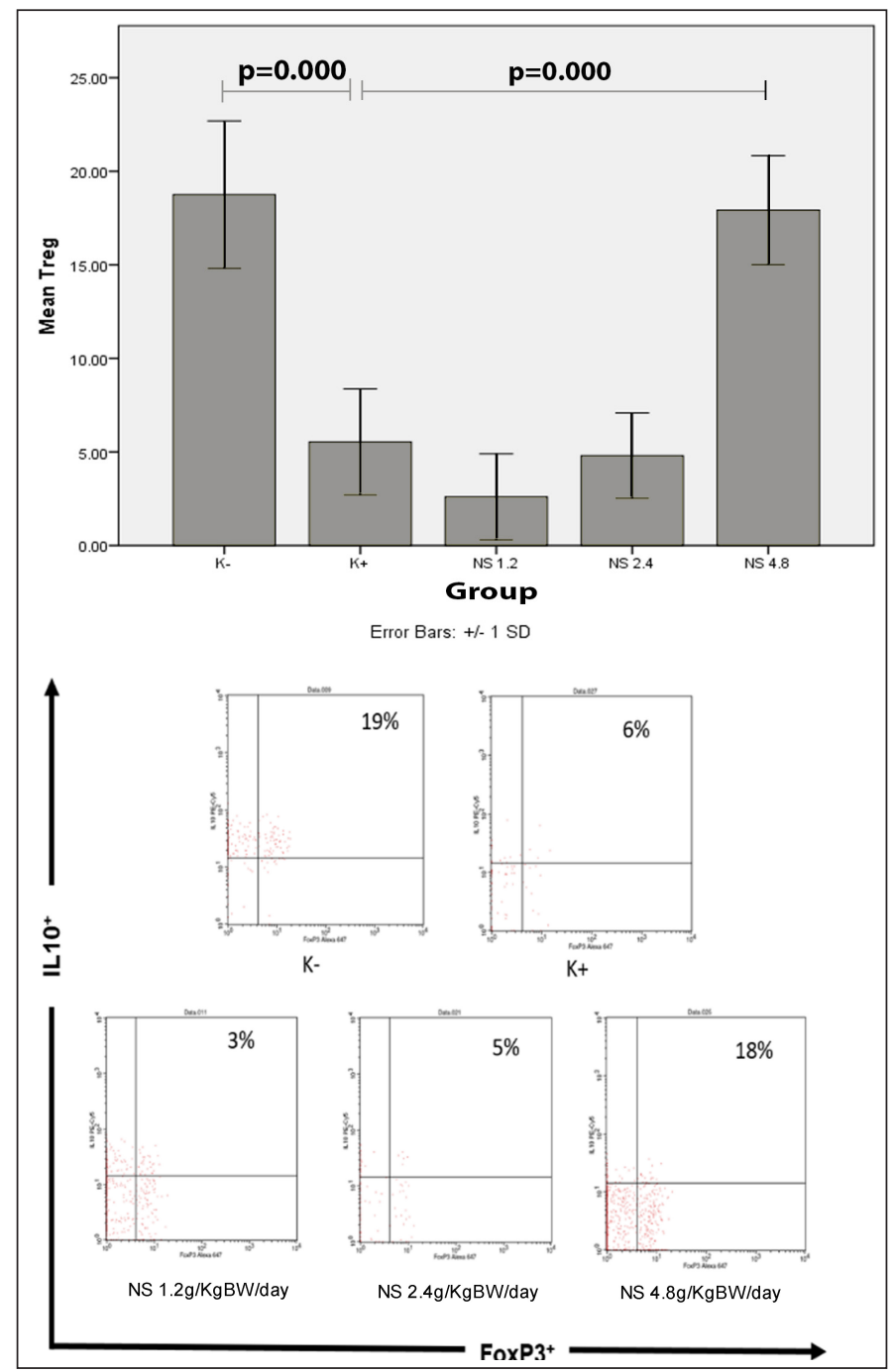

Figure 4. (A) Diagram of Treg cell percentage mean between groups. (B) Results of Treg cell percentage examination $\left(\mathrm{CD} 4^{+} \mathrm{CD} 25^{+} \mathrm{FoxP}^{+} \mathrm{IL} 10^{+}\right)$using flow cytometry.

Table 5. Post hoc Tukey significance value between two groups.

\begin{tabular}{|c|c|c|}
\hline Group 1 & Group 2 & $p$-values \\
\hline \multirow[t]{4}{*}{$\mathrm{K}^{-}$} & $\mathrm{K}^{+}$ & 0.000 \\
\hline & NS 1.2 & 0.000 \\
\hline & NS 2.4 & 0.000 \\
\hline & NS 4.8 & 0.991 \\
\hline \multirow[t]{3}{*}{$\mathrm{K}^{+}$} & NS 1.2 & 0.519 \\
\hline & NS 2.4 & 0.994 \\
\hline & NS 4.8 & 0.000 \\
\hline \multirow[t]{2}{*}{ NS 1.2} & NS 2.4 & 0.755 \\
\hline & NS 4.8 & 0.000 \\
\hline NS 2.4 & NS 4.8 & 0.000 \\
\hline \multirow[t]{4}{*}{ NS 4.8} & K- & 0.991 \\
\hline & $\mathrm{K}^{+}$ & 0.000 \\
\hline & NS 1.2 & 0.000 \\
\hline & NS 2.4 & 0.000 \\
\hline
\end{tabular}




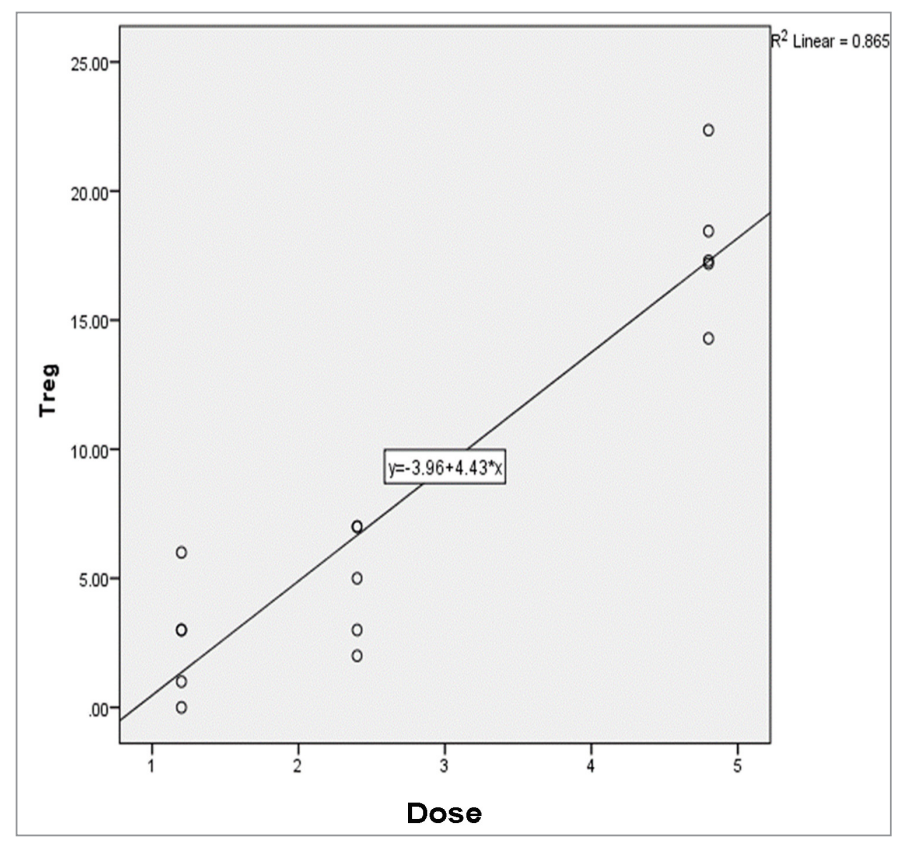

Figure 5. Graph of simple linear regression equation between $N$. sativa dose and Treg percentage.

are known to have decreased the number of $\mathrm{CD} 4{ }^{+} \mathrm{CD} 25^{+}$cells because the Foxp $3^{+}$Treg cells in SLE patients have a decreased ability to suppress CD4 and CD8 cell proliferation. Thus, the decreased Treg causes failure to inhibit autoreactive B cells and $\mathrm{T}$ cells in mice and humans with SLE (Rottman and Willis, 2010).

Increasing the number of Tregs is one of the therapeutic targets in preventing the progression of SLE. In this study, giving the NS extract with the dose of $4.8 \mathrm{~g} / \mathrm{kgBW} /$ day for 1 month increases the number of Tregs in PIL mice. So it could be interpreted that NS extract was effective in returning Treg production because the results were almost the same as the healthy group mice. This occurs because therapy helps compensate mechanisms for increasing the number of Tregs in response to high proinflammatory immune cells that must inhibit both their proliferation and activation (Arvey et al., 2020). In addition, the results for the percentage of Treg in the 1.2 and $2.4 \mathrm{~g} / \mathrm{kgBW} /$ day groups were lower than the control group, although not significantly different because the two doses were not yet in the therapeutic window or not sufficient to restore the Treg function in SLE. Another factor is that there is a stress mechanism that can activate the hypothalamic-pituitary-adrenocortical axis which stimulates the release of corticosterone and the production of proinflammatory cytokines such as IL-6 and IL-17. If NS is given in adequate doses, there will be a stress compensation and the Treg will return to high. There will be suppression of Treg due to stress mechanisms, whereas this did not occur at doses of NS 4.8 because of the adequate doses (Harpaz et al., 2013).

\section{CONCLUSION}

In conclusion, there is a relation between the increase of NS extract dose with the decrease of anti-dsDNA level and the increase of Treg percentage. The most effective NS dose in this research is $4.8 \mathrm{~g} / \mathrm{kgBW} / \mathrm{day}$. NS has the potential to be an adjuvant therapy for SLE.

\section{AUTHOR CONTRIBUTIONS}

All authors made substantial contributions to conception and design, acquisition of data, or analysis and interpretation of data; took part in drafting the article or revising it critically for important intellectual content; agreed to submit to the current journal; gave final approval of the version to be published; and agree to be accountable for all aspects of the work. All the authors are eligible to be an author as per the international committee of medical journal editors (ICMJE) requirements/guidelines.

\section{FUNDING}

There is no funding to report.

\section{CONFLICTS OF INTEREST}

The authors report no financial or any other conflicts of interest in this work.

\section{ETHICAL APPROVALS}

The study protocol was approved by the Ethical Committee for Animal Experimentation in the Faculty of Medicine, Universitas Brawijaya (325/EC/KEPK-S1-PD/11/2019).

\section{PUBLISHER'S NOTE}

This journal remains neutral with regard to jurisdictional claims in published institutional affiliation.

\section{REFERENCES}

Ahmad A, Husain A, Mujeeb M, Khan SA, Najmi AK, Siddique NA, Damanhouri ZA, Anwar F. A review on therapeutic potential of Nigella sativa: a miracle herb. Asian Pac J Trop Biomed, 2013; 3(5):337-52.

Albaar TM, Handono K, Poeranto S, Nurdiana, Arifin S, Hartanti KD, Gumilang R, Dharmesta NA, Saputri NV, Anggita A, Dananjaya V. Efficacy studies of Treg activation using dsDNA desensitization inhibits immune function without side effect in lupus mice model. AIP Conf Proc, 2019; 2108(1):020037.

Arvey A, Rowe M, Legutki JB, An G, Gollapudi A, Lei A, Colston B, Putterman C, Smith D, Stiles J, Tarasow T. Age-associated changes in the circulating human antibody repertoire are upregulated in autoimmunity. Immun Ageing, 2020; 17(1):1-6.

Atik N, Putri Pratiwi S, Hamijoyo L. Correlation between C-reactive protein with malondialdehyde in systemic lupus erythematosus patients. Int J Rheumatol, 2020; Article ID 8078412:5.

Balaha MF, Tanaka H, Yamashita H, Rahman MN, Inagaki N. Oral Nigella sativa oil ameliorates ovalbumin-induced bronchial asthma in mice. Int Immunopharmacol, 2012; 14(2):224-31. 33.

Barlianto W, Kusuma HC, Widodo MA, Suharto S. Crude extract of black seed (Nigella sativa) can modulate T CD4+ CD25+ FoxP3+ lymphocytes in asthmatic mouse model. Paediatr Respir Rev, 2012; 13(1):S54.

Barlianto W, Wulandari D, Chusniyah M, Kusuma HM, Prawiro SR. 2018. Improvement of Th17/Treg balance and asthma control test score by Nigella sativa supplementation in asthmatic children: a new approach to managing asthma. Turk J Immunol, 2018; 6(1):1-7.

Benaroya Research Institute. Autoimmune diseases. Immune system disease. Benaroya Research Institute, Seattle, WA, 2019.

Botnick I, Xue W, Bar E, Ibdah M, Schwartz A, Joel DM, Lev E, Fait A, Lewinsohn E. Distribution of primary and specialized metabolites in Nigella sativa seeds, a spice with vast traditional and historical uses. Molecules, 2012; 17(9):10159-77.

Cunningham MA, Wirth JR, Scott JL, Eudaly J, Collins EL, Gilkeson GS. Early ovariectomy results in reduced numbers of $\mathrm{CD} 11 \mathrm{c}+/$ $\mathrm{CD} 11 \mathrm{~b}+$ spleen cells and impacts disease expression in murine lupus. Front Immunol, 2016; 7:31. 
de Zubiria Salgado A, Herrera-Diaz C. Lupus nephritis: an overview of recent findings. Autoimmune Dis, 2012; 2012.

Fanouriakis A, Kostopoulou M, Alunno A, Aringer M, Bajema I, Boletis JN, Cervera R, Doria A, Gordon C, Govoni M, Houssiau F, Jayne D, Kouloumas M, Kuhn A, Larsen JL, Lerstrøm K, Moroni G, Mosca M, Schneider M, Smolen JS, Svenungsson E, Tesar V, Tincani A, Troldborg A, van Vollenhoven R, Wenzel J, Bertsias G, Boumpas DT. 2019 update of the EULAR recommendations for the management of systemic lupus erythematosus. Ann Rheum Dis, 2019; 78(6):736-45.

Farhangi MA, Dehghan P, Tajmiri S, Abbasi MM. The effects of Nigella sativa on thyroid function, serum VEGF-1, Nesfatin-1 and anthropometric features in patients with Hashimoto's thyroiditis: a randomized controlled trial. BMC Complement Altern Med, 2016; 16(1):19. 41.

Finzel S, Schaffer S, Rizzi M, Voll RE. Pathogenese des systemischen lupus erythematodes. Z Rheumatol, 2018; 77(9):789-98.

Harpaz I, Abutbul S, Nemirovsky A, Gal R, Cohen H, Monsonego A. Chronic exposure to stress predisposes to higher autoimmune susceptibility in C $57 \mathrm{BL} / 6$ mice: glucocorticoids as a double-edged sword. Eur J Immunol, 2013; 43(3):758-69.

Hersh AO, von Scheven E, Yazdany J, Panopalis P, Trupin L, Julian L, Katz P, Criswell LA, Yelin E. Differences in long-term disease activity and treatment of adult patients with childhood-and adult-onset systemic lupus erythematosus. Arthritis Care Res, 2009; 61(1):13-20.

Hmza AJ, Omar E, Adnan A, Osman MT. Nigella sativa oil has significant repairing ability of damaged pancreatic tissue occurs in induced type 1 diabetes mellitus. Glob J Pharmacol, 2013; 7(1):14-9.

Huang N, Perl A. Metabolism as a target for modulation in autoimmune diseases. Trends Immunol, 2018; 39(7):562-76.

Infantino M, Grossi V, Benucci M, Li Gobbi F, Damiani A, Manfredi M. The impact of biological treatments on the anti-dsDNA and anti-nucleosome tests. Lupus, 2018; 27(1):40-8. 31.

Jaryal A, Vikrant S. Current status of lupus nephritis. Indian J Med Res, 2017; 145(2):167.

Mahajan A, Herrmann M, Muñoz LE. Clearance deficiency and cell death pathways: a model for the pathogenesis of SLE. Front Immunol, 2016; 7:35

Maidhof W, Hilas O. Lupus: an overview of the disease and management options. Pharm Ther, 2012; 37(4):240.

Manan A, Hussain N. Mutational analysis of DNAse I gene in Pakistani SLE patients. J Clin Cell Immunol, 2016; 7(419):2.

Miles K, Heaney J, Sibinska Z, Salter D, Savill J, Gray D, Gray M. A tolerogenic role for Toll-like receptor 9 is revealed by B-cell interaction with DNA complexes expressed on apoptotic cells. Proc Natl Acad Sci, 2012; 109(3):887-92.

Noor NA, Fahmy HM, Mohammed FF, Elsayed AA, Radwan NM. Nigella sativa amliorates inflammation and demyelination in the experimental autoimmune encephalomyelitis-induced Wistar rats. Int J Clin Exp Pathol, 2015; 8(6):6269.
Palumbo ML, Canzobre MC, Pascuan CG, Rios H, Wald M, Genaro AM. Stress induced cognitive deficit is differentially modulated in $\mathrm{BALB} / \mathrm{c}$ and $\mathrm{C} 57 \mathrm{~B} 1 / 6$ mice: correlation with Th1/Th2 balance after stress exposure. J Neuroimmunol, 2010; 218(1-2):12-20.

Pan $\mathrm{L}, \mathrm{Lu} \mathrm{MP}$, Wang JH, Xu M, Yang SR. Immunological pathogenesis and treatment of systemic lupus erythematosus. World $\mathrm{J}$ Pediatr, 2020; 16(1):19-30.

Petri M, Orbai AM, Alarcón GS, Gordon C, Merrill JT, Fortin PR, Bruce IN, Isenberg D, Wallace DJ, Nived O, Sturfelt G. Derivation and validation of the SLICC classification criteria for systemic lupus erythematosus. Arthritis Rheum, 2012; 64(8):2677-86.

Rekvig OP. Anti-dsDNA antibodies as a classification criterion and a diagnostic marker for systemic lupus erythematosus: critical remarks. Clin Exp Immunol, 2015; 179(1):5-10.

Rottman JB, Willis CR. Mouse models of systemic lupus erythematosus reveal a complex pathogenesis. Vet Pathol, 2010; 47(4):664 76.

Rubinstein TB, Mowrey WB, Ilowite NT, Wahezi DM, Childhood Arthritis and Rheumatology Research Alliance INVESTIGATORS, Abramson L, Anderson E, Andrew M, Battle N, Becker M, Benham H. Delays to care in pediatric lupus patients: data from the childhood arthritis and rheumatology research alliance legacy registry. Arthritis Care Res, 2018; 70(3):420-7. 9(5):A271-6.

Stojanovich L. Stress and autoimmunity. Autoimmun Rev, 2010;

Tahernia L, Namazi S, Rezaei N, Ziaee V. Cytokines in systemic lupus erythematosus: their role in pathogenesis of disease and possible therapeutic opportunities. Rheumatol Res, 2017; 2(1):1-9.

Walker MK, Boberg JR, Walsh MT, Wolf V, Trujillo A, Duke MS, Palme R, Felton LA. A less stressful alternative to oral gavage for pharmacological and toxicological studies in mice. Toxicol Appl Pharmacol, 2012; 260(1):65-9.

Wichainun R, Kasitanon N, Wangkaew S, Hongsongkiat S, Sukitawut W, Louthrenoo W. Sensitivity and specificity of ANA and antidsDNA in the diagnosis of systemic lupus erythematosus: a comparison using control sera obtained from healthy individuals and patients with multiple medical problems. Asian Pac J Allergy Immunol, 2013; 31(4):292.

How to cite this article:

Guritno T, Barlianto W, Wulandari D, Amru WA. Effect Nigella sativa extract for balancing immune response in pristane induced lupus mice model. J Appl Pharm Sci, 2021; 11(07):146-152. 